\title{
High-resolution intra-ring oxygen isotope measurements across fossil wood indicate above-freezing wintertime temperatures in the Arctic during the Eocene
}

\author{
ADRIAN CHARLES ${ }^{1}$ AND DR. BRIAN A. SCHUBERT ${ }^{2}$
}

${ }^{1}$ School of Geosciences, University of Louisiana at Lafayette, LA, 70504, (Adrian.Charles1@louisiana.edu)

${ }^{2}$ School of Geosciences, Univ. of Louisiana at Lafayette, LA, 70504 (Brian.Schubert@louisiana.edu)

During the Eocene Epoch, large forested ecosystems existed north of the Arctic Circle under $\mathrm{CO} 2$ concentrations 2-3 x pre-industrial levels. Evidence for these unique ecosystems is provided by extensive collections and descriptions of plant and animal fossils collected by numerous workers across multiple sites within Arctic Canada. The stratigraphy, sedimentology, and tectonic context of these fossil sites, especially those located on Axel Heiberg Island, Ellesmere Island, and Banks Island have been extensively described. Multiple approaches have been used to determine the climate environment in which these Eocene polar forests lived, and include study of related modern-day taxa, leaf area index, and isotope studies of vertebrate fossils. Here we present a new reconstruction for seasonal temperature in the Arctic during the Eocene based on high-resolution, intra-ring stable carbon and oxygen isotope data measured across fossil wood dated to 45 to $55 \mathrm{Ma}$. We calculate that Arctic forests thrived under average July and January temperatures of 20 to $22{ }^{\circ} \mathrm{C}$ and -2 to $6{ }^{\circ} \mathrm{C}$, respectively. These temperatures suggest mean annual temperatures $22{ }^{\circ} \mathrm{C}$ warmer than present day, but with substantially more warming in winter $\left(\sim 30^{\circ} \mathrm{C}\right)$ than summer $\left(\sim 10^{\circ} \mathrm{C}\right)$. These data represent the first quantitative estimates for seasonal temperature in the Arctic during the Eocene using fossil wood, and demonstrate that above-freezing year-round temperatures are possible in the Arctic under sustained periods of elevated $\mathrm{CO} 2$. 